\title{
Article
}

https://dx.doi.org/10.4314/iijikm.v9i3.3

\section{Career Progression of Librarians in Nigeria and Ghana Universities}

\section{Fehintola N. Onifade}

Federal University of Agriculture Abeokuta, Nigeria

Clara C. Okoro

Babcock University Ilishan-Remo, Nigeria

Gifty O. Boakye

Maranatha University College Sowutuom, Accra Ghana

\section{Information}

Impact

\author{
Information Impact: Journal \\ of information and \\ knowledge management \\ 2018, Vol. 9 (3) Pg. 33-46 \\ ISSN: $2141-4297$ (print) \\ ISSN: 2360 - 994X (e-version)
}

\begin{abstract}
The study examines the career structure of librarians in Nigeria and Ghana Universities. It compares the criteria used in the employment and other components of career progression. Questionnaire and interview were used as instruments of data collection. 50 copies of the questionnaire were administered through the postal service, online mail and personally in international conferences. A purposeful sampling technique was used to select the sample.30 heads of university libraries participated in Nigeria and 20 heads of libraries participated from Ghana. The data were analysed through SPSS and the frequency count and percentage were used for the result. The study reveals that the career structure of librarians in Nigeria and Ghana universities was similar but not the same and that librarians in the two countries are highly educated. Recommendations were also made to improve their status
\end{abstract}

\section{Key words: Career, Career structure, University libraries, Nigeria, Ghana,}

\section{Introduction}

A functional library, especially in an academic arena is the life wire of any university system, and that is why university libraries are often referred to as citadels of learning and the nerve centres of their universities. Consequently, it is assumed that no university can rise above the level of services offered by her library. Thus, for a university library to remain afloat and for efficient and effective services, competent and dedicated librarians are needed to drive this objective. However, a good number of librarians are not comfortable with the low rating of libraries and librarians by the general public. Coupled with this is the lack of appreciation and near lack of recognition of library services by the public especially in developing nations like Nigeria and Ghana. This had been attributed to misconception or sheer ignorance of the duties of librarians. A well-articulated and comprehensive career structure for librarians is therefore 
needed for sustainable and enduring advancement in the profession. The aim of this study therefore, is to examine the career structure of librarians in Nigeria and Ghana universities.

\section{Objectives of the study}

The main objective of this study is to examine the career structure and development of librarians in the university libraries in Nigeria and Ghana, while the specific objectives are;

1. to ascertain the criteria used in employing librarians in Nigeria and Ghana universities;

2. to assess the career structure and development of librarians in Nigeria and Ghana universities;

3. to compare the career structure and development of librarians in Nigeria and Ghana universities.

\section{Literature Review}

\section{Career Structure and Development in University Libraries}

A career is known as an occupation, or a chosen profession which generates some income for an individual. It is an ultimate phenomenon that involves building and creating an identity that determines the relevance of a person in the society he belongs to (Yusuf \& Ilo 2012). Career structure therefore, refers to a recognised pattern of advancement in a profession; this includes rules, entitlements, skills and responsibility attached to various levels of job within an organisation. A career is also said to be an occupation which is undertaken for a significant period of a person's life. Pavlina (2007) postulated that enjoying a career is one of the important goals in life; therefore, it is important for people to choose a career in which they will be fulfilled and happy. On the other hand, the traditional concept of career development is the progression up an ordered hierarchy within an organisation or profession (Campbell, Marcella \& Baxter, 2001). Thus, career development is increasingly seen not as being chosen, but as being constructed, through the series of choices about learning and work that people make throughout their lives (Cullen, 2013). Career development therefore, can be defined as an organised approach used to match employee goals with the business needs of the agency in support of workforce development initiatives (Petricca-Harris \& McKenna, 2013).

Over the years, a number of studies have shown that career development has several implications for both employees and organisations. Wilson and Halpin (2006) stated that most successful organisations adjust their talent management strategies to focus on development, and to provide solutions that put their employees in control of their own careers. Tomaszewski and MacDonald (2009) also observed that, employee development is a prerequisite to employee productivity and sustenance of competitive advantage in the challenging business environment nowadays. Furthermore, Cooke (2012) pointed out that through innovation and employee career development process; an organisation will benefit from improved performance, mobilise talent as needed, adjust to rapid changes in the environment and thereby retain their most critical talents. Many organisations therefore, have, realised that developing the talents and skills of their workforces in the global economy is the chief means of staying competitive. Consequently, 
employees' career developmental needs must be consciously linked with the organisation's workforce needs as well as its strategic direction.

Librarianship in Nigeria has evolved over the years to the extent that the concept of the profession and the practitioners is changing for the better. The history of librarianship in Nigeria as discussed by Aguolu and Aguolu (2002) revealed a continual conflict between two opposing factors: those who want libraries and fought to have them established and those who resisted their establishment and expansion. Nevertheless, based on Lancour (1958), and Sharr (1963) reports on library needs of West Africa and Northern Nigeria respectively, two library schools were established in Nigeria. The first school was the Institute of Librarianship which was opened in 1960 at the University College, Ibadan and the second was at the Ahmadu Bello University. Zaria in 1968. These institutions were built on different philosophical and professional orientations. While the Ibadan library school started with one year basic professional program leading to the award of the post-graduate diploma in accordance with the main objective of the Institute which was "to educate the leadership for the library profession", the Zaria library school mounted an undergraduate program leading to the award of the Bachelor of Library Science (BLS) degree based on its' objective "to train professional librarians at all levels with wellrounded education up to international standard- - -"

Several authors have expressed the view that librarianship as discipline does not enjoy the same status when compare with discipline like law, Medicine, Engineering, and Business administration in Nigeria (Ochogus, 2007, Madu, Odenigbo \& Tongs, 2014). This is rather unfortunate, as Library and Information Science is usually placed at the bottom when discussing high-flying profession. It is, however, believed that it is the value that librarians place on themselves and the profession that will eventually change the negative public opinion about the profession (Okoro, 2009). The fact that librarianship is a service profession cannot be contested, and by extension, a career in librarianship is both academic and professional. Anafulu (2007) claimed that all practitioners of a profession should be bonded in an association which is the face and voice of the profession, thus; the Nigerian Library Association was established in 1962. One cannot discuss the development of librarianship in Nigeria without touching on the contentious issue of academic or faculty status of practitioners in Nigerian university libraries. The debate on whether librarians should be accorded faculty status was as heated as well as controversial that it tore both universities and practitioners among themselves in the 1980s. A good number of Vice-Chancellors of Nigerian universities argued that if librarians want to be cloaked in faculty titles, they must be prepared to 'publish or perish' as their counterparts in the departments. Librarians on the other hand, argued that they work longer hours than the teaching staff, engaged in shift duties and also provide scholarly services. They felt the publication requirements for librarians should be reduced while more emphasis should be placed on the service aspect for promotion purposes. Nevertheless, Salisu (2001) suggested that librarians should take the issue of research and publication seriously to avoid the double-standards as observed in some universities when it comes to the assessment of librarians for higher faculty positions. Librarians 
these days have strong academic background to enable them cope with the rigors of research. Presently in Nigerian universities, quite a lot of librarians are professors and Doctoral degree holders. The long battle that shaped the career structure and the development of librarians in Nigeria finally came to an end in 1993 when the National Universities Commission (NUC), the regulatory body of all universities in Nigeria, directed in a circular that librarians in all federal universities should be accorded academic status in appointments and promotions.

The history of librarianship in Ghana was greatly influenced by Evelyn Evans who went to Gold Coast (now Ghana) in 1945 as the British Council Librarian. She was said to have campaigned for library services for good five years (Sturges, 2001) and eventually the Gold Coast Library Board was established in 1950. Later in 1962 the government of Ghana established a school of library under the Ghana Library Board (Alemna 1989). The school offered the 'Associateship-level' program of the British Library Association between 1961 and 1964. In 1965 the school was moved to and absorbed by the University of Ghana and became a full-fledged Department of Library Studies within the Faculty of Social Science. In 1976, it became the Centre for Archival Education in English-speaking Africa under ICA/UNDP partnership with the Department of Library Studies and was renamed the Department of Library and Archival Studies. Initially, the Department offered certificate, non-degree diploma and post graduate diploma programmes. In 1999 the under-graduate degree in Information Studies (DIS) was introduced and the name was changed to the Department of Information Studies.

The classification of the librarians in Ghana university libraries depends on the structure and size of the library in which they are employed; for instance, university libraries in Ghana have different career structures. However, the following positions are common to all university libraries in Ghana; Librarian, followed by the Deputy Librarian, then the Senior Assistant Librarians, Assistant Librarians and Junior Assistant Librarians followed by Senior Library Assistants, and then the Junior Library Assistants (Badu, 2005). However, according to Lamptey, Boateng and Antwi (2013), progression from one position to another is attained either through long-term service or educational upgrade and scholarly publications. Senyah (2003) pointed out that even though promotions largely depend on advancement in education; most library staff in Ghana were not recognised and given the necessary promotional packages after the attainment of a higher educational qualification, hence, academic librarians' promotion is not automatic in Ghana. It therefore, assumed that despite the important role of university libraries in educational research and national development, librarians working in Ghana university libraries were not been fairly treated.

\section{Methodology}

A survey research design was used for this study. 50 heads of university libraries participated in the survey. A purposive sampling technique was used to select the sample as only those who gave their consents to partake in the study were covered, hence, twenty heads of university libraries participated from Ghana while thirty heads of university libraries participated in Nigeria. The main instrument used to collect data was a self-designed questionnaire, which was complemented by informal interview conducted with some heads of libraries, both in Nigeria and 
Ghana. Different methods were used to administer and collect the questionnaire to/from heads of university libraries; some were mailed online; some were mailed through post while some were distributed during international conferences such as IFLA. All the 50 copies of the questionnaire were retrieved but only 43 copies of the questionnaire were duly completed and were used for the analysis, representing $86 \%$ response rate. The data was analysed through the SPSS software and the result was expressed through frequency count and percentages.

\section{Findings and Discussion}

\section{Demographic Information}

The result of the study shows that $17(39.5 \%)$ of the total respondents were from Ghana while $26(60.5 \%)$ respondents were from Nigeria. The majority of the respondents $19(44.2 \%)$ had masters' degree and $16(37.2 \%)$ are $\mathrm{PhD}$ holders. Only $1(2.3 \%)$ respondent had first degree in Library Science while 4(9.3\%) respondents had other degrees not related to Library Science. The data collected also revealed that majority of the respondents $19(44.2 \%)$ were in age bracket of 50-60 years while the lowest $2(4.6 \%)$ were in age bracket of 30-40years. $28(65.1 \%)$ of the respondents were males while $15(34.9 \%)$ were females. It can therefore, be deduced that most heads of libraries in Nigeria and Ghana are matured men and ladies that have obtained post graduate degrees in Library and Information Science.

\section{Criteria for Employing Librarians in Nigeria and Ghana}

The respondents were asked to indicate the criteria used in employing librarians in Nigeria and Ghana, they were allowed to tick more than one option as it applies to their situation.

Table 1: Criteria for Employing Librarians in Nigeria and Ghana

\begin{tabular}{|l|l|l|}
\hline \multicolumn{2}{|c|}{ Nigeria (N= 58) } \\
\hline Criteria & Frequency & $\%$ \\
\hline First degree in Library and Information Science & 3 & 5.2 \\
\hline Master/degree in Library and Information Science & 25 & 43.1 \\
\hline Must have some publications & 20 & 34.5 \\
\hline Must have Subject Background & 0 & 0 \\
\hline Must be accredited by a licensing body & 10 & 17.2 \\
\hline & 58 & 100 \\
\hline
\end{tabular}




\begin{tabular}{|c|c|c|}
\hline \multicolumn{3}{|c|}{ Ghana University Libraries $N=25$} \\
\hline Criteria & Frequency & $\%$ \\
\hline First degree in Library and Information science & 5 & 20 \\
\hline Master/degree in Library and Information science & 13 & 52 \\
\hline Must have some publications & 7 & 28 \\
\hline Must have Subject Background & 0 & 0 \\
\hline Must be accredited by licensing body & 0 & 0 \\
\hline & 25 & 100 \\
\hline
\end{tabular}

The analysis as presented in Table 1 revealed that 25(43.1\%) of the total responses show that the major criterion used for employing librarians in Nigeria university libraries is masters' degree in Library and Information Science. In addition to this, 20(34.5\%) of the responses indicated that paper publication is equally important while 10(17.2\%) show that librarians also need to be certified by an accrediting body; the Librarians' Registration Council of Nigeria (LRCN). Moreover, the result shows that it is not necessary for librarians to have subject background before being employed by the universities. Likewise in Ghana, 13(52\%) out of the responses indicated that librarians must have at least a Masters' degree in Library and Information Science. $7(28 \%)$ responses also indicated that librarians are expected to published. However, they do not need to register or be certified by any accrediting body. It can therefore, be inferred that most universities in Nigeria and Ghana employ librarians with postgraduate degrees in LIS.

Table 2: Career Structure of Librarian in Nigeria $(N=26)$

\begin{tabular}{|l|l|l|l|}
\hline Career Structure & Description & Frequency & $\%$ \\
\hline Status of Librarian & Academic & 26 & 100 \\
\hline Nomenclatures of librarians & $\begin{array}{l}\text { Librarian II, Librarian I, Senior } \\
\text { Librarian, Principal Librarian, } \\
\text { Deputy University Librarian, } \\
\text { University Librarian }\end{array}$ & 20 & 77 \\
\cline { 2 - 4 } & $\begin{array}{l}\text { Assistant Librarian, Librarian } \\
\text { II, Librarian I, Senior Librarian, } \\
\text { Reader Librarian/Deputy } \\
\text { University Librarian, } \\
\text { University Librarian/ Professor }\end{array}$ & 6 & 23 \\
\hline Wo hours per week & 26 & 100 \\
\hline
\end{tabular}




\begin{tabular}{|c|c|c|c|}
\hline Head of Libraries & $\begin{array}{l}\text { Are Principal officers and are } \\
\text { responsible to Vice-Chancellor }\end{array}$ & 26 & 100 \\
\hline Qualification of Head of libraries & $\begin{array}{l}\mathrm{PhD} \\
\mathrm{MLS}\end{array}$ & $\begin{array}{l}16 \\
8\end{array}$ & $\begin{array}{l}61.5 \\
30.7\end{array}$ \\
\hline \multicolumn{4}{|l|}{ Career Progression } \\
\hline \multirow[t]{2}{*}{ Duration for Promotion } & $\begin{array}{l}\text { Librarians are entitled to } \\
\text { promotion every three years }\end{array}$ & 26 & 100 \\
\hline & $\begin{array}{l}\text { a). Stagnate at Principal } \\
\text { Librarian except through } \\
\text { appointment. } \\
\text { b). Some get to the peak } \\
\text { through promotion }\end{array}$ & 20 & 19.2 \\
\hline Policy on Continuous Education & $\begin{array}{l}\text { a). Yes there is a Formal Policy } \\
\text { b). Yes there is an Informal } \\
\text { Policy } \\
\text { c). No Policy at all } \\
\text { d) Neutral }\end{array}$ & $\begin{array}{l}11 \\
11 \\
3 \\
1\end{array}$ & $\begin{array}{l}42.3 \\
42.3 \\
11.5 \\
3.8\end{array}$ \\
\hline Budget Allocation & $\begin{array}{l}\text { Yes } \\
\text { No } \\
\text { Neutral }\end{array}$ & $\begin{array}{l}17 \\
4 \\
5\end{array}$ & $\begin{array}{l}65.4 \\
15.4 \\
19.2\end{array}$ \\
\hline Privileges enjoyed by Librarians & $\begin{array}{l}\text { a). Research Leave } \\
\text { b). Research allowance } \\
\text { c). Research Grants } \\
\text { d) Conference grants } \\
\text { e, Others }\end{array}$ & $\begin{array}{l}26 \\
26 \\
16 \\
26\end{array}$ & $\begin{array}{l}100 \\
100 \\
62 \\
100 \\
-\end{array}$ \\
\hline Publication needed for promotion & Yes & 26 & 100 \\
\hline
\end{tabular}

The result presented in the Table 2 shows that all the 26(100\%) respondents indicated that librarians are regarded as academic staff in their universities. The nomenclature used for ranking librarians in Nigerian universities is of two types. 20(77\%) respondents indicated that librarians are ranked from the level of librarian II up to the level of University Librarian. Another $6(23 \%)$ respondents indicated that the nomenclature used for librarians in their universities aligns with that of other faculty members which starts from the level of Assistant Librarian (equal to Assistant Lecturer) and then progresses to Professorial cadre (The University Librarian). One can deduce that the ranking system for librarians in Nigerian universities is not uniform. The respondents 26(100\%) however, indicated that they are Principal Officers in their respective universities; this implies that they are responsible to their Vice-Chancellors. The data further revealed that $16(61.5 \%)$ of the total respondents had $\mathrm{PhD}$ degrees while $8(30.7 \%)$ had Masters' 
degrees. This reveals that most heads of university libraries in Nigeria are Doctorate degree holders.

On career progression, 20(77\%) out of the total respondents indicated that librarians do not always get to the peak of their career as most of them usually stagnate at the level of Principal Librarian while 5(19.2\%) respondents indicated that librarians can reach the peak through promotions in their universities. Concerning the career development, majority of the respondents $22(84.6 \%)$ indicated that they have continuing education policy in their universities; though 11(42.3\%) respondents out of this, stated that the policy is an informal one; while the other $11(42.3 \%)$ revealed that theirs is a formal policy on continuing education. Moreover, $17(65.4 \%)$ respondents stated that the policy is backed up with budget allocation while 4(15.4\%) indicated that there is no budget for theirs. This negates Ezeani (2008) report which stated that most academic libraries in Nigeria do not have staff development policies and those who do, are not critically dedicated to it. In addition, all the respondents stated that librarians are entitled to specific academic allowances for self-development. They also confirmed that publication is a requirement for librarians' promotion and that there is a specific duration for promotion between the levels which is usually three years except where the candidate do not meet up with the criteria.

Table 3: Career Structure of Librarian in Ghana $(\mathbf{N}=17)$

\begin{tabular}{|l|l|l|l|}
\hline Career Structure & Description & Frequency & $\%$ \\
\hline Status of Librarians & Academic & 9 & 52.9 \\
& Non Academic & 6 & 35.3 \\
\hline Nomenclatures of librarians & Junior Assistant Librarian, & 17 & 100 \\
& Assistant Librarian, & & \\
& Senior Assistant Librarian, Deputy & & \\
& University Librarian, University & & \\
& Librarian & & 100 \\
\hline Working Hours & 40 hours per week & 17 & 76.5 \\
\hline Head of Libraries & 1. Are Principal officers and are & 13 & \\
& responsible to Vice-Chancellor & 4 & 23.5 \\
\hline Qualification of Head of libraries & 2. Administrative Officers & 4 & 5.9 \\
& BSC & 1 & 64.7 \\
& MLS/M.Phil & 4 & 23.5 \\
\hline Progression & Others & & \\
\hline
\end{tabular}




\begin{tabular}{|l|l|l|l|}
\hline Duration for Promotion & 5years & 9 & 53 \\
& 6years & 6 & 35.3 \\
& 7 years & 2 & 11.7 \\
\hline & $\begin{array}{l}\text { Librarians can get to the peak } \\
\text { through promotion }\end{array}$ & 15 & 88.2 \\
\hline Policy on Continuous Education & $\begin{array}{l}\text { a). Yes there is a Formal Policy } \\
\text { b). Yes there is an Informal Policy } \\
\text { c). No Policy at all } \\
\text { d) Neutral }\end{array}$ & 9 & 52 \\
& Yes & 8 & 47 \\
\hline Budget Allocation & No & 3 & 17.6 \\
\hline Privileges enjoyed by Librarians & $\begin{array}{l}\text { a). Research Leave } \\
\text { b). Research allowance }\end{array}$ & 14 & 82.4 \\
\hline & c). Research Grants & 6 & 13 \\
& d) Conference grants & 14 & \\
& e, Others & 14 & \\
\hline Publication needed for promotion & Yes & - & \\
& No & 16 & 94.1 \\
& & 5.9 \\
\hline
\end{tabular}

In Ghana, the analysis in table 3 reveals that 9(52.9\%) respondents indicated that librarians are regarded as academic staff in their universities, while 6(35.3\%) respondents stated that they are classified as administrative staff in their universities. This denotes that not all librarians working in Ghana universities are regarded as academic staff. All the 17(100\%) respondents indicated that librarians are ranked from Junior Assistant Librarian through to University Librarian. This implies that there is a uniform nomenclature for librarians in Ghana. However, only 13(76.5\%) respondents claimed they are Principal Officers while 4(23.5\%) stated that they are administrative officers. On educational qualification 11(64.7\%) of respondents had masters'M.Phil. degrees, while one is a B.Sc. degree holder. This shows that most heads of libraries in Ghana universities had at least Masters' degree in Library and Information Science.

Concerning career progression of librarians in Ghana universities, 9(53\%) of the respondents indicated that librarians spend at least five years on a level before they are promoted to another, $6(35.3 \%)$ stated six years while $2(11.7 \%)$ respondents indicate 8 years. This confirms that there is no fixed duration for librarians' promotion from one level to the other in Ghana. However, $15(88.2 \%)$ of the respondents indicated that librarians can get to the peak of their career through promotion. All the respondents except one indicated that publication is also a criterion for librarians' promotion in Ghana universities. Regarding continuing education policy, $8(47.1 \%)$ of the respondents revealed that they have a policy on continuing education while, $9(53 \%)$ respondents showed that they do not have any policy, those who have, specified that it is an informal policy. 
Table 4: Comparison of the Career Structure and Development of Librarians in Nigeria and Ghana Universities

\begin{tabular}{|l|l|l|}
\hline Structure & Ghana & Nigeria \\
\hline $\begin{array}{l}\text { Status of librarians in University } \\
\text { System }\end{array}$ & Academic / Administration & Academic \\
\hline Criteria for employing librarian & MA/M.Phil. degree & MLIS/PhD degree \\
\hline Nomenclatures of librarians & Uniform & Not Uniform \\
\hline Qualification & $\begin{array}{l}\text { Most head of libraries are } \\
\text { Masters' degree holders }\end{array}$ & $\begin{array}{l}\text { Most head of Libraries are PhD } \\
\text { holders }\end{array}$ \\
\hline Development & No Licensing body & Have Licensing body \\
\hline Licensing Body & Available & Available \\
\hline Academic Allowances & No fixed periods & Every three years \\
\hline Promotion periods & $\begin{array}{l}\text { Librarians can get to the } \\
\text { peak through promotion }\end{array}$ & $\begin{array}{l}\text { Some get to the peak through } \\
\text { promotion/appointment } \\
\text { Some stagnated at various level }\end{array}$ \\
\hline Career Progression & Available- Informal & Available- Informal/Formal \\
\hline Policy on Continuous Education & Needed for promotion & Needed for Promotion \\
\hline Publications & & \\
\hline
\end{tabular}

The study reveals that Librarians in Nigerian universities are regarded as academic staff and they are also entitled to some academics allowances enjoyed by their teaching colleagues. This is supported by the Code of Practice of Academic Staff Union of Universities (ASUU) of 2012 under article 3 which stated that "any person who is engaged full-time in a University as Lecturer, Research Fellow or Academic Librarian in a university shall be deemed to be members of the union" (Ajidahun, 2015). In contrast to Nigeria not all librarians in Ghana universities are regarded as academic staff some are known as administrative staff depending on the size and type of the university in which they are employed. Antwi (1993) cited by Thompson, Amuda, and Akeriwe (2015) confirmed that there is no uniformity in the status accorded librarians in Ghanaian universities. He stated further that the situation is even more complex in some universities as only those with higher qualification (M.Phil) may apply to be accorded academic status. In the interview conducted with some heads of libraries in Ghana it was established that some major universities like Kwame Nkrumah University of Science and Technology, University of Education, Weneba, University of Cape Coast, University of Development Studies and University of Ghana have even introduced a dual track-academic and administrative tracks for librarians. This means that librarians can either choose to be academics or be an administrator and will be assessed as such.

It was also revealed that the major criterion used in employing librarians in Nigerian universities is the Masters' degree, because librarians are rated and remunerated as their teaching colleagues. However, findings from the interview revealed that some private universities still 
employ librarians with first degree as Graduate Librarians and later train them, but the general practice is to employ Master degree holders. Likewise in Ghana, a librarian must have at least a postgraduate' degree before he/she can be employed in the university. One of the head of library interviewed stated that "the reality in Ghana is that librarians in university libraries must have a minimum of a Masters' degree in Library Studies; because first degree holders are not considered as professional librarians". Lamptey, Boateng and Antwi (2013) confirmed this, that the senior staffs who are professional librarians are holders of postgraduate qualifications in Library Studies and Information Science.

The study moreover, showed that there are two types of nomenclatures used in ranking librarians in Nigerian universities, while the conventional type (i.e. Librarian II, Librarian I, Senior Librarian, Principal Librarian, Deputy University Librarian, University Librarian) is still being used by the majority, the new one is evolving that aligns with that of the teaching academic staff in few universities. The interview with some heads of libraries had it that this was done in order to equate librarians with their counterpart in the faculty. They emphasised that librarians are also involve in other tasks such teaching and other university assignment as committee members. In Ghana, the nomenclature used in ranking librarians is uniform and the lowest entry point for librarians in any university in Ghana is at the level of a Junior Assistant Librarian, while the highest is the University Librarian which is by appointment.

In terms of career progression, Nigerian librarians earn promotion every three years if they fulfil the promotion criteria which include certain number of publications and other conditions as set up by their universities. It was, however, gathered from the interview that the number of publications required by librarians in order to move from one level to the other differs from university to university. In some universities, librarians are expected to have higher number of publications than their teaching colleagues while the case is vice versa in others. Librarians' promotions and appointments therefore involve a high academic content in terms of scholarly publishing in Nigeria. Salaam and Onifade (2009) noted that most university libraries in Nigeria require that librarians should possess $\mathrm{PhD}$ degrees before they can be promoted or even be offered appointment. The data collected and the interview indicate that librarians cannot be promoted beyond the level of Principal Librarian/Senior Librarian in some universities except if they are appointed as Deputy University Librarians. In cases like this, there can only be at most two Deputy Librarians and others will have to mark time except there is another vacancy or seek their fortune elsewhere. However there are some exceptional cases in few universities such as Federal University of Agriculture, Abeokuta, Babcock University, Ilishan, University of Calabar, University of Nigeria, Nsukka and University of Lagos, Akoka where the career structure for librarians had been changed from the conventional one. Librarians in these universities can get promoted to the Professorial level by the Appointments and Promotion Committee of their universities once the criteria are met.

In Ghana, promotion from one level to the other is not automatic; the duration between promotions is not fixed. Lamptey et al (2013) stated that promotion is based on long years of service. However, from the data collected, the minimum duration seem to be five years, while 
publication is also used as one of the criteria for promotion. Although there is no automatic promotion for librarians in Ghana universities, librarians can get to the peak of their career through promotion.

Moreover, the study also reveals that there are continuing education policies for librarians in the two countries, while that of Ghana is mostly informal_and not fully backed up with funding that of Nigeria is based on a fifty-fifty ratio. It should be noted that it is absolutely essential for librarians to engage actively in continuing education programmes if they are to remain professionally relevant and more importantly, if they are to provide services that will meet the challenges imposed on them.

\section{Conclusion}

The study reveals that career structures of librarians in Nigerian and Ghanaian universities are similar but are not the same. The nomenclatures used for ranking librarians are different but the librarians have similar responsibilities and work for forty hours a week in the two countries. Furthermore, while the trend in Nigerian university libraries is that librarians cannot progress beyond the level of Senior/Principal Librarian without obtaining a $\mathrm{PhD}$ Degree, librarians in Ghana universities are promoted with M.Phil. Degree. In addition, there is no clearly defined continuing education policies for librarians in the two countries whereas, competent staff consistently exposed to relevant development trainings is an asset anywhere. It should be noted that a university library's single most valuable resource is its workforce. Thus, without educated, well-trained, and motivated librarians, university libraries will not be able to meet the needs of its patrons or the challenges that face the institution (Connor 2009). It is thus obvious from the study that librarians are highly educated professionals who have obtained specific training before taken up their jobs. They are adequately qualified personnel, therefore; they deserve to have a well package career structure. However, the following recommendations are made to improve the career structure of librarians in the two countries:

1. Academic librarians in Nigeria should align their nomenclature with that of their teaching colleagues and make sure that the same conditions of service apply to them.

2. Librarians in Ghana universities must take a stand as to where to belong; either academics or administrative in order to avoid double standard.

3. There should be a regular and fix duration for promotion of librarians in Ghana universities.

4. The universities should sponsor librarians for continuing education program to improve, update their knowledge and skills in this age of rapid technology innovations.

5. Librarians in the two countries could establish exchange programs with one another to compare notes on best practise. 


\section{References}

Aguolu, C. C. (2002). Problems facing the library profession in Nigeria. In Aguolu, C. C.(ed) Libraries and Information Management in Nigeria. Maiduguri, ED-Linform Services.

Ajidahun, C. (2015). Librarians in crisis of status, identity and marginalization. Journal of Balkan Librarian Union, 3(2), 40-47.

Alemna, A.A. (1998). Education and training of the future librarian in Ghana, Librarian Career Development, 6(1), 3 - 6.

Alemna, A.A. (2001). Perception of continuing education for librarianship in Ghana. New Library World, 102(1/2), 44-48.

Anafulu, J. C. (2007). The library profession in the $21^{\text {st }}$ century. Heartland Journal of Library and Information Science. 1(1), 1-7.

Badu, E. E (2005) Employee motivation in university libraries in Ghana: a comparative analysis, Information Development. 21(1) 38-46,

Campbell, F., Marcella, R. and Baxter, G. (2000). Professional development and the recently qualified information and library studies professional: factors affecting success in attainment of the UK library association associate's status, Education for Information, 18(2/3), 169-199.

Cooke, N. A. (2012). Professional development 2.0 for librarians: developing an online personal learning network (PLN), Library Hi Tech News, 29(3), 1 - 9.

Cullen, J.G. (2013). Vocational ideation and management career development. Journal of Management Development, 32(9), 932 - 944.

Ezeani, C.N (2008) Gender as a determinant of job satisfaction of academic librarian in Nigeria. Ghana Library Journal. 20(2) 61-64

Madu, U.A, Odenigbo, P and Tongs, H. (2014) Relationship between school library management and student choice of career in librarianship. Information and Knowledge Management 4(4) $75-81$

Ochogwu, M.G. (2007). The internalities and externalities of library and information delivery services in Nigeria by year 2015. Nigerian Libraries. 40, 15-26

Okoro, C.C. (2009). Career choice of students of Library and Information Science in Tertiary Institutions in Imo State, Nigeria.The Information Technologist, 6(1), 53-59

Lamptey, R.B., Boateng, M.S. and Antwi, I.K. UDS (2013). Motivation and performance of librarians in public universities in Ghana, Library Philosophy and Practice (e-journal). Retrieved from: http://digitalcommons.unl.edu/libphilprac/911, on December 4, 2017

Pavlina, S (2007) Career and commitment. Retrieved from on November 9, 2017

Petricca-Harris, A and Mckenna, S. (2013) Identity struggle, professional development and career: A career?life history of a human resource management professional. Journal of Management Development 32(8), 823-835

Salaam, M.O and Onifade, F.N (2009) Academic status and doctorate degree requirement for promotion of librarian in Nigerian university libraries. Libraries and Philosophy 
Practice. March 1-6

Salisu, T. M. (2001) Status of librarians in Nigeria: A pragmatic study. In Olanlokun, S. O. and Salisu, T. M. (ed) Libraries and Librarianship in Nigeria: A festschrift for Ezekiel E.

Bankole. Lagos: Ikafa Press.

Senyah, Y. (2003). Motivation and productivity in academic libraries: a case study of the Kwame Nkrumah University of Science and Technology Library, Kumasi'. Journal of Science and Technology. 23(2), 80-82.

Sturges, P. (2001) The poverty of librarianship: National library of services of anglophone Africa in the post-independence era. Libri, 51, 38-48

Thomas, V.K., Satpathi, C. and Satpathi, J.N. (2010). Emerging challenges in academic librarianship and role of library associations in professional updating", Library Management, 31(8), 594-609.

Thompson, E.S, Amuda, J.M and Akeriwe, M.L (2015) Twenty years of academic librarianship in Ghana: the university of development library experience. UDS International Journal of Development, 1(1) 1-12 Retrieved from http://udsijd.oru

Tomaszewski, R. and MacDonald, K.I. (2009). Identifying subject-specific conferences as professional development opportunities for academic librarians, Journal of Academic Librarianship, 35(6), 583-590.

Vicedo, M. and Davis, A. (2010). Professional development on a dime (or less): learning and connecting in the new economy, College and Research Libraries News, 71(1), 30-31,

Wilson, K.M. and Halpin, E. (2006). Convergence and professional identity in the academic library, Journal of Librarianship and Information Science, 38(2), 79-91.

Yusuf, F and Ilo, P (2012) Career commitment of staff in academic libraries: a comparative study of two private university libraries in Ogun State Nigeria, Nigerian Library Link. 10(1\&2) 35-48 